OPEN ACCESS

Edited by:

Meixue Zhou,

University of Tasmania,

Australia

Reviewed by:

Petronia Carillo,

University of Campania

Luigi Vanvitelli,

Italy

Miguel A. Rosales,

Institute of Natural Resources and Agrobiology of Seville (CSIC), Spain

*Correspondence:

Honghong Wu

honghong.wu@mail.hzau.edu.cn

Zhaohu Li

lizhaohu@cau.edu.cn

Specialty section:

This article was submitted to

Plant Abiotic Stress,

a section of the journal

Frontiers in Plant Science

Received: 02 July 2019

Accepted: 11 October 2019

Published: 08 November 2019

Citation:

Wu H and Li Z (2019) The Importance

of $\mathrm{Cl}^{-}$Exclusion and Vacuolar $\mathrm{Cl}^{-}$

Sequestration: Revisiting the Role of

$\mathrm{Cl}^{-}$Transport in Plant Salt Tolerance.

Front. Plant Sci. 10:1418.

doi: $10.3389 /$ fpls.2019.01418

\section{The Importance of $\mathrm{Cl}^{-}$Exclusion and Vacuolar $\mathrm{Cl}^{-}$Sequestration: Revisiting the Role of $\mathrm{Cl}^{-}$Transport in Plant Salt Tolerance}

\author{
Honghong $W^{1,2,3 *}$ and Zhaohu $\mathrm{Li}^{1,2 *}$
}

${ }^{1}$ College of Plant Science \& Technology, Huazhong Agricultural University, Wuhan, China, ${ }^{2}$ College of Agronomy and Biotechnology, China Agricultural University, Beijing, China, ${ }^{3}$ Department of Botany and Plant Sciences, University of California, Riverside, CA, United States

Salinity threatens agricultural production systems across the globe. While the major focus of plant researchers working in the field of salinity stress tolerance has always been on sodium and potassium, the transport patterns and physiological roles of $\mathrm{Cl}^{-}$in plant salt stress responses are studied much less. In recent years, the role of $\mathrm{Cl}^{-}$in plant salinity stress tolerance has been revisited and has received more attention. This review attempts to address the gap in knowledge of the role of $\mathrm{Cl}^{-}$transport in plant salinity stress tolerance. $\mathrm{Cl}^{-}$transport, $\mathrm{Cl}^{-}$exclusion, vacuolar $\mathrm{Cl}^{-}$sequestration, the specificity of mechanisms employed in different plant species to control shoot $\mathrm{Cl}^{-}$accumulation, and the identity of channels and transporters involved in $\mathrm{Cl}^{-}$transport in salt stressed plants are discussed. The importance of the electrochemical gradient across the tonoplast, for vacuolar $\mathrm{Cl}^{-}$sequestration, is highlighted. The toxicity of $\mathrm{Cl}^{-}$from $\mathrm{CaCl}_{2}$ is briefly reviewed separately to that of $\mathrm{Cl}^{-}$from $\mathrm{NaCl}$.

Keywords: $\mathrm{Cl}^{-}$exclusion, $\mathrm{Cl}^{-}$transport, ion channels and transporters, salinity stress tolerance, vacuolar $\mathrm{Cl}^{-}$sequestration

\section{INTRODUCTION}

Soil salinity affects nearly $50 \%$ of all irrigated land in the world, and is a major constraint to crop yield (Fita et al., 2015). To meet the projected demand of feeding 9.3 billion people by 2050, global agricultural production must be increased by $60 \%$ from its $2005-2007$ levels (van Ittersum et al., 2016). Therefore, understanding the mechanisms that underlie plant salt tolerance, especially its ion transport-related traits, is important, since it would allow the breeding of salt tolerant crops and thus mitigate the possible food shortage in the future.

Traditionally, adverse effects of soil salinity have been attributed to with $\mathrm{Na}^{+}$toxicity, prompting the majority of studies on this topic (Munns and Tester, 2008; Horie et al., 2012; Deinlein et al., 2014; Maathuis, 2014; Wu et al., 2015; Hanin et al., 2016; Wu et al.,, 2018a). However, an increase in $\mathrm{Na}^{+}$content (Munns and Tester, 2008; Wu, 2018) is always accompanied by $\mathrm{Cl}^{-}$accumulation (Tavakkoli et al., 2010) and $\mathrm{K}^{+}$loss (Wu et al., 2018b) in plants exposed to salt $(\mathrm{NaCl})$ stress. $\mathrm{K}^{+}$is the major inorganic nutrient cation in non-halophytes (Dreyer and Uozumi, 2011), and plays important roles in plant cell activities (Anschütz et al., 2014; Shabala and Pottosin, 2014; Wu et al., 2018c) and stress responses (Wang et al., 2013). $\mathrm{Cl}^{-}$is a plant micronutrient and regulates leaf osmotic potential, and turgor, and stimulates growth in plants (Franco-Navarro et al., 2016). However high 
$\mathrm{Cl}^{-}$solutions are toxic, and impair photosynthesis and growth (Tavakkoli et al., 2010; Tavakkoli et al., 2011). Specific reasons for these detrimental effects are much less understood than those of $\mathrm{Na}^{+}$, but the excessive accumulation of $\mathrm{Cl}^{-}$in chloroplasts is one effect (Seemann and Critchley, 1985; Geilfus, 2018b).

In recent years, the role of $\mathrm{Cl}^{-}$in plant salinity stress tolerance has attracted more attention. The role of $\mathrm{Cl}^{-}$in halophytes was reviewed by (Bazihizina et al., 2019). They suggest that rather than targeting $\mathrm{Cl}^{-}$exclusion, a better way to breed salt tolerant crops would be to improve the selectivity of the broadly selective anion-transporting proteins. $\mathrm{Cl}^{-}$as an essential micronutrient and its beneficial role in plants (Raven, 2017; Wege et al., 2017), the role of $\mathrm{Cl}^{-}$in organelle development (Geilfus, 2018a; Geilfus, 2018b), and control of $\mathrm{Cl}^{-}$transport in plants (Li et al., 2017b) have been recently reviewed. Moreover, it is suggested nowadays that $\mathrm{Cl}^{-}$is a beneficial macronutrient for plants (Franco-Navarro et al., 2016; Franco-Navarro et al., 2019). Unlike the abovementioned recent reviews, the present mini review is focused on the main traits related to controlling $\mathrm{Cl}^{-}$transport, and its role in plant salt tolerance.

\section{CL-, A LARGELY OVERLOOKED ION IN PLANT SALT TOLERANCE}

$\mathrm{Cl}^{-}$is an essential micronutrient in plants. In some plant species e.g. soybean, and woody plants such as avocado, $\mathrm{Cl}^{-}$showed more significant toxic effect than $\mathrm{Na}^{+}$since they are better at excluding $\mathrm{Na}^{+}$from the leaf blades than $\mathrm{Cl}^{-}$(Munns and Tester, 2008). The toxicity threshold of $\mathrm{Cl}^{-}$is estimated to be $15-50$ and 4-7 mg per gram dry weight for $\mathrm{Cl}^{-}$tolerant and sensitive species, respectively (Xu et al., 1999). Besides its roles in photosynthesis and in membrane potential stabilization, $\mathrm{Cl}^{-}$also regulates enzyme activities in the cytoplasm and is involved in turgor and $\mathrm{pH}$ regulation (Teakle and Tyerman, 2010). Low $\mathrm{Cl}^{-}(<$ $5 \mathrm{mM}$ ) resulted in increased leaf area and biomass in tobacco plants (Franco-Navarro et al., 2016), whereas high $\mathrm{Cl}^{-}$(> 120 $\mathrm{mM}$ ) resulted in decreased biomass production in barley plants (Tavakkoli et al., 2011). Whereas high $\mathrm{Cl}^{-}$(over 4 mg g-1 FW) shows toxicity due to interference with PSII quantum yield and photosynthetic electron transport rate (Tavakkoli et al., 2011; Carillo et al., 2019), $\mathrm{Cl}^{-}$in a range of $0.2-2 \mathrm{mg} \mathrm{g}^{-1} \mathrm{FW}$ (fresh weight) can function in the stabilization of the oxygen-evolving complex of photosystem II, in the maintenance of electrical potential in cell membranes, regulation of tonoplast $\mathrm{H}^{+}$-ATPase and enzyme activities (Marschner 1995; Broadly et al., 2012; Carillo et al., 2019). In tobacco, up to $4 \mathrm{mg} \mathrm{g}^{-1} \mathrm{FW}, \mathrm{Cl}^{-}$can be important for the maintenance of water homeostasis (FrancoNavarro et al., 2016).

For most crop plants, $\mathrm{Na}^{+}$is more toxic than $\mathrm{Cl}^{-}$. Salinity stress in some plant species, e.g. soybeans and woody plant species such as citrus, is due to more pronounced $\mathrm{Cl}^{-}$toxicity (White and Broadley 2001). Such species are comparatively effective in excluding $\mathrm{Na}^{+}$, but do not prevent $\mathrm{Cl}^{-}$from accumulating to toxic levels in leaves (Munns and Tester, 2008). It is known that $\mathrm{Na}^{+}$ toxicity is due to the similarity of the hydrated ionic radii of $\mathrm{Na}^{+}$ to that of $\mathrm{K}^{+}$, and is thus in competition with $\mathrm{K}^{+}$for binding sites on enzymes that depend on $\mathrm{K}^{+}$for activation. This is clearly not the case of $\mathrm{Cl}^{-}$. Antagonism between $\mathrm{Cl}^{-}$and $\mathrm{NO}_{3}{ }^{-}$can result in a reduction in the uptake and storage of nitrogen (Li et al., 2017b), which is the important source for protein synthesis and many metabolism products. At high concentrations of $\mathrm{Cl}^{-}$, limited nitrogen supply as a result of antagonism between $\mathrm{Cl}^{-}$and $\mathrm{NO}_{3}^{-}$ could be a reason for its toxicity in salinized plants. In the presence of high $\mathrm{Cl}^{-}$, a decrease of shoot $\mathrm{NO}_{3}{ }^{-}$to $\mathrm{Cl}^{-}$ratio is correlated with a significant shoot biomass reduction in Arabidopsis, and the overexpression SLAH1 (a homologue of the slow type anion channel SLAC1) (Qiu et al., 2016) (Cubero-Font et al., 2016). Li et al. (2017b) recently proposed that the $\mathrm{NO}_{3}{ }^{-} / \mathrm{Cl}^{-}$ratio might be used as a salt tolerance indicator, similar to the $\mathrm{K}^{+} / \mathrm{Na}^{+}$ratio.

\section{CACL $_{2}$ BASED CL- TOXICITY IN ORNAMENTAL AND HORTICULTURAL PLANT SPECIES}

Besides sodium salts, a wide range of other dissolved salts (e.g. those of $\mathrm{Mg}^{2+}$ and $\mathrm{Ca}^{2+}$ salts) are also present in saline soils (Tavakkoli et al., 2010). When reclaimed water is used for irrigation, (Wang et al., 2017), $\mathrm{B}^{3+}, \mathrm{Ca}^{2+}, \mathrm{Cl}^{-}, \mathrm{Na}^{+}$, and $\mathrm{SO}_{4}{ }^{2-}$ and their salts may be prevalent (Martinez and Clark, 2012; Nackley et al., 2015). In this context, there is potential for $\mathrm{Cl}^{-}$toxicity to arise from $\mathrm{CaCl}_{2}$ instead of $\mathrm{NaCl}$. Further, $\mathrm{Cl}^{-}$ toxicity may arise from the use of $\mathrm{Cl}^{-}$salts, (such as $\mathrm{KCl}$ and $\mathrm{CaCl}_{2}$ ), as fertilizers. For example, to decrease the accumulation of nitrate in leafy vegetables, (to meet EU directives), calcium $\mathrm{Cl}^{-}$is sometimes substituted for calcium nitrate (Carillo et al., 2019). Low level $\mathrm{Ca}^{2+}$ (below $10 \mathrm{mM}$ ) is known to ameliorate $\mathrm{NaCl}$ induced salinity stress symptoms in many plant species, e.g. Arabidopsis (Shabala et al., 2006), rice (Rahman et al., 2016), wheat (Al-Whaibi et al., 2012), barley (Cramer et al., 1991), and Calligonum mongolicum (Xu et al., 2017), etc. However, under moderate $\mathrm{CaCl}_{2}$ treatment (above $20 \mathrm{mM}$ ), greater $\mathrm{Cl}^{-}$toxicity was observed in some ornamental, (e.g. Callistemon citrinus and Viburnum lucidum), and horticultural species, (e.g. Ocimumu basilicum), (Borghesi et al., 2013; Collaa et al., 2013; Borgognone et al., 2014; Carillo et al., 2019; Cirillo1 et al., 2019). These studies showed that $\mathrm{CaCl}_{2}$ salinity is able to induce ion imbalance and hyperosmotic stress even more severe than that of $\mathrm{NaCl}$, strongly reducing plant growth and yield. These results can be partly attributed to the toxic effects of $\mathrm{Cl}^{-}$, (since $\mathrm{CaCl}_{2}$ has twice the $\mathrm{Cl}^{-}$that the same number of moles of $\mathrm{NaCl}$ carries), for which the uptake and transport to leaves could be less controlled than that of $\mathrm{Na}^{+}$(Collaa et al., 2013) in these studied ornamental and horticultural plant species.

\section{CHANNELS AND TRANSPORTERS IN CL- TRANSPORT}

To date, the most commonly reported gene families for $\mathrm{Cl}^{-}$ channels are characterized as slow anion channels (SLAC channels), $\mathrm{Cl}^{-}$channels (CLC), and aluminium activated malate transporters (ALMT transporters) (Skerrett and Tyerman, 1994). 
Seven CLCs (AtCLCa to AtCLCg, channels or transporters), localized in various intracellular membranes including the tonoplast (AtCLCa, AtCLCb, AtCLCc, and AtCLCg), thylakoid membrane (AtCLCe), and Golgi membrane (AtCLCd and AtCLCf), were found in Arabidopsis (Barbier-Brygoo et al., 2011; Herdean et al., 2016a). Other possible $\mathrm{Cl}^{-}$candidate channels (including the putative one) are mechanosensitive channels (Maksaev and Haswell, 2012; Hamilton et al., 2015), AtVCCN1 (Herdean et al., 2016b), VvNRT1.4, and VvNAXT1 (Henderson et al., 2014). For $\mathrm{Cl}^{-}$transporters, ALMT (aluminium-activated malate transporters) (De Angeli et al., 2013), CCC (cation chloride co-transporter) (Colmenero-Flores et al., 2007), DTX/MATE (detoxification efflux carrier/multidrug and toxic compound extrusion transporters) (Zhang et al., 2017), and AtNPF2 (Li et al., 2017b) are reported to be involved in $\mathrm{Cl}^{-}$ transport in salinized plants.

Besides $\mathrm{Na}^{+}$toxicity, salinity (both $\mathrm{Na}^{+}$and $\mathrm{Cl}^{-}$) also causes osmotic stress in plants. $\mathrm{Cl}^{-}$influx has been observed in plant cells subjected to salinity (Shabala et al., 2005). Interestingly, hyperosmotic stress also induced net $\mathrm{Cl}^{-}$uptake in bean mesophyll cells (Shabala et al., 2000). This leads to the question of whether the mechanosensitive channels might play a direct or indirect role in $\mathrm{Cl}^{-}$transport in plant cells under salt stress. Falke et al. (1988) identified the first mechanosensitive $\mathrm{Cl}^{-}$channel in tobacco protoplasts. Maksaev and Haswell (2012) found that MSL10 (mechanosensitive channel-like 10) shows a preference for $\mathrm{Cl}^{-}$over $\mathrm{Na}^{+}$(6:1) and might be involved in $\mathrm{Cl}^{-}$efflux to relieve the membrane tension once the channel opens. MSL8 $\left(\mathrm{Cl}^{-}\right.$over $\left.\mathrm{Na}^{+}, 6.3: 1\right)$ was also found to sense and respond to changes in Arabidopsis pollen hydration, and also to germination associated membrane tension (Hamilton et al., 2015). The role of mechanosensitive channels in $\mathrm{Cl}^{-}$transport in plant salt stress responses should be studied in greater detail.

The channels and transporters involved in $\mathrm{Cl}^{-}$transport in plants under salt stress are summarized in Figure 1. Interesting topics with a potential for future study include dissecting the possible role and contributions of $\mathrm{Cl}^{-}$transport in plant overall salt tolerance, identifying specific channels/transporters involved in $\mathrm{Cl}^{-}$transport, and establishing which contribute to salt tolerance, as well as investigating a possible link to other signalling events e.g. $\mathrm{Ca}^{2+}$ and ROS waves.

\section{REGULATION OF CL- TRANSPORT IN PLANT SALINITY STRESS RESPONSE}

\section{Controlling Shoot $\mathrm{Cl}^{-}$Accumulation: The Role of Root and Shoot Cl- Exclusion Differs Between Plant Species}

$\mathrm{Cl}^{-}$in soil presents mainly as $\mathrm{Cl}^{-}$, and its movement within the soil is largely determined by water flows (White and Broadley, 2001). Compared to the advanced study of $\mathrm{Na}^{+}$transport, much less data is available for $\mathrm{Cl}^{-}$transport in plants under salinity. Teakle and Tyerman (2010) summarized several traits of $\mathrm{Cl}^{-}$movement related to plant salt tolerance: 1) reduced net $\mathrm{Cl}^{-}$uptake by roots, 2) reduced net xylem loading of $\mathrm{Cl}^{-}, 3$ ) intercellular compartmentation of $\left.\mathrm{Cl}^{-}, 4\right)$ intracellular compartmentation of

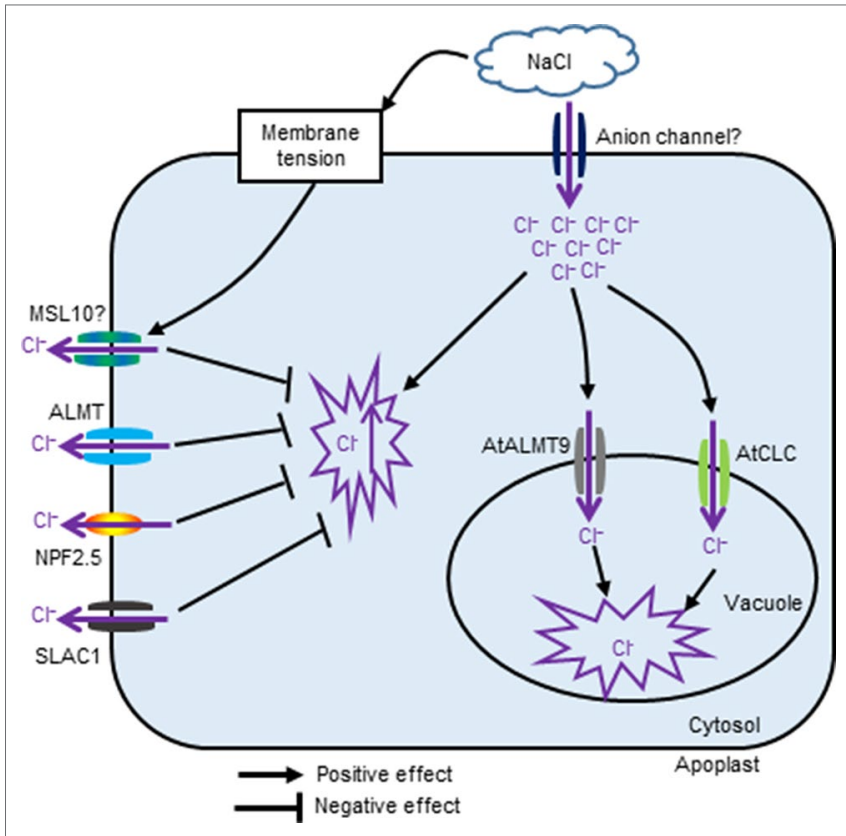

FIGURE 1 | The proposed schematic showing channels and transporters involved in $\mathrm{Cl}^{-}$transport in plants under salinity stress.

$\mathrm{Cl}^{-}$, and 5) phloem recirculation and translocation within the plant. Efficient exclusion of $\mathrm{Cl}^{-}$from either roots or shoots could avoid excessive accumulation of $\mathrm{Cl}^{-}$in plant tissues.

A significantly lower shoot $\mathrm{Cl}^{-}$concentration was found in salt tolerant barley varieties than in sensitive ones (Tavakkoli et al., 2011), suggesting that controlling the accumulation of shoot $\mathrm{Cl}^{-}$is important for overall salt tolerance. However, whether this is due to root $\mathrm{Cl}^{-}$exclusion or shoot $\mathrm{Cl}^{-}$exclusion still needs to be answered. A question also remains over the differences that may exist between plant species. Chen et al. (2013) showed that wild type soybean has stronger root $\mathrm{Cl}^{-}$exclusion (efflux) than the relatively salt sensitive cultivated soybean varieties, suggesting the important role of root $\mathrm{Cl}^{-}$exclusion in soybean salt tolerance. In citrus rootstocks, tolerance in salt tolerant species, which have significantly lower shoot $\mathrm{Cl}^{-}$, is mostly conferred by superior root resistance to $\mathrm{Cl}^{-}$uptake (Moya et al., 2003). This is further demonstrated by Brumos et al. (2010). In barley, to the contrary, less accumulation of shoot $\mathrm{Cl}^{-}$in salt tolerant than sensitive species (Tavakkoli et al., 2011) may not be due to root $\mathrm{Cl}^{-}$exclusion. It has been shown that although cytosolic and vacuolar $\mathrm{Cl}^{-}$concentration is not different between salt tolerant and sensitive barley varieties, a 73\% higher $(P<0.001)$ apoplast $\mathrm{Cl}^{-}$in root cortical cells was found in salt sensitive compared to tolerant barley varieties (Flowers and Hajibagheri, 2001). Also, a strong and positive correlation was found between grain yield and transcripts of HvSLAH1 and HvSLAC1, (anion channels that mediate $\mathrm{Cl}^{-}$efflux), in barley leaves (Liu et al., 2014). This suggests that shoot $\mathrm{Cl}^{-}$exclusion in barley is associated with overall salt tolerance. Shoot $\mathrm{Cl}^{-}$exclusion is also associated with salt tolerance in some other species, e.g. grapevine, Lotus, and Glycine etc. (Teakle and Tyerman, 2010). Significantly lower xylem $\mathrm{Cl}^{-}$was found in relatively salt tolerant varieties compared to salt sensitive 
varieties of durum wheat (Line 149 vs Tamaroi) (Läuchli et al., 2008), and Lotus corniculatus (L. tenuis vs L. corniculatus) (Teakle et al., 2007). Overall, the mechanisms controlling shoot $\mathrm{Cl}^{-}$ accumulation evidently do differ between plant species.

\section{Shoot and Root $\mathrm{Cl}^{-}$Exclusion: Which Channels or Transporters Play the Major Roles?}

To date, the topic of key transporters and channels involved in shoot and root $\mathrm{Cl}^{-}$exclusion is still not yet fully explored. In terms of breeding salt tolerant species, knowing the key transporters and channels controlling $\mathrm{Cl}^{-}$exclusion could be very helpful. For example, overexpression of the genes SOS1, (encoding a key $\mathrm{Na}^{+}$/ $\mathrm{H}^{+}$antiporter for $\mathrm{Na}^{+}$extrusion from cytosol to apoplast), (Yang et al., 2009; Yue et al., 2012), and NHX1, (encoding a key $\mathrm{K}^{+}, \mathrm{Na}^{+}$/ $\mathrm{H}^{+}$exchanger for sequestrating $\mathrm{Na}^{+}$from cytosol to vacuole), (Apse et al., 1999; Zhang and Blumwald, 2001; Chen et al., 2007; Gouiaa et al., 2012), resulted in increased overall salt tolerance in many plant species. Pyramiding with the approach proposed by Bazihizina et al. (2019), (that of improving the selectivity of the broadly selective anion-transporting proteins), may yield enhanced $\mathrm{Cl}^{-}$exclusion ability and be an important strategy for breeding salt tolerant crops.

SLAC1, a channel located in the plasma membrane, is highly permeable to malate and $\mathrm{Cl}^{-}$(Negi et al., 2008). Transgenic overexpression of AtSLAC1 in tobacco BY-2 cells enhanced cryptogein (an elicitor able to induce ROS production)-induced $\mathrm{Cl}^{-}$efflux (Kurusu et al., 2013). Plants with a mutation in slac1, (the gene for SLAC1 which mediates $\mathrm{Cl}^{-}$efflux), also showed increased $\mathrm{Cl}^{-}$content in guard cells (Negi et al., 2008). Together, these reports suggest that SLAC1 is an anion channel which is involved in $\mathrm{Cl}^{-}$exclusion. SLAH1, a homologue of SLAC1, modulates shoot $\mathrm{Cl}^{-}$accumulation, and thus salt tolerance, in Arabidopsis (Cubero-Font et al., 2016; Qiu et al., 2016). It has been shown that the upregulation of the genes HvSLAH1 and HvSLAC1 in leaves is linked with higher barley grain yield in the field (Liu et al., 2014).

Besides SLAC1, CLC channels/transporters and ALMT transporters might also play a role in $\mathrm{Cl}^{-}$exclusion. Herdean et al. (2016a) proposed that the thylakoid $\mathrm{Cl}^{-}$channel AtCLCe functions in $\mathrm{Cl}^{-}$homeostasis. Wei et al. (2016) showed that by regulating $\mathrm{Cl}^{-}$accumulation, the GmCLC1 channel confers enhanced salt tolerance in soybean. The ALMT (aluminium activated malate transporter) protein family is unique to plants and is able to mediate anion fluxes across cellular membranes (Barbier-Brygoo et al., 2011). At high external $\mathrm{Cl}^{-}$, the permeability ratio of TaALMT1, (Piñeros et al., 2008), and ZmALMT2 (Ligaba et al., 2012), towards malate and $\mathrm{Cl}^{-}$is around 1 , suggesting that these channels might be able to mediate a substantial amount of $\mathrm{Cl}^{-}$efflux. AtALMT12, a plasma membrane targeted anion transporter, is mainly permeable to $\mathrm{Cl}^{-}$and nitrate and is involved in stomatal closure (Meyer et al., 2010). Furthermore, Li et al. (2017a) found that AtNPF2.5 (NRT1/ PTR Family protein), a $\mathrm{Cl}^{-}$permeable transporter predominantly expressed in root cortical cells, modulates $\mathrm{Cl}^{-}$efflux from roots. Mutation of the AtNPF2.5 gene in Arabidopsis resulted in impaired root exclusion and thus a higher shoot $\mathrm{Cl}^{-}$accumulation (Li et al., 2017a). Overexpression of this gene might increase root $\mathrm{Cl}^{-}$exclusion and thus may allow enhancement of overall salt tolerance in plants. Further, besides its role in limiting shoot $\mathrm{Na}^{+}$accumulation, the endoplasmic reticulum located transporter GmSALT3 (encoded by "salt tolerance-associated gene on chromosome 3") (Guan et al., 2014) was found to be involved in leaf $\mathrm{Cl}^{-}$exclusion in soybean under salinity stress (Liu et al., 2016). Moreover, the possibility of involvement of the CCC (cation chloride co-transporter) family in $\mathrm{Cl}^{-}$exclusion cannot be completely ruled out. For example, a ccc2 mutant showed significant higher shoot $\mathrm{Cl}^{-}$than wild type Arabidopsis, and shoot $\mathrm{Cl}^{-}$content was significantly reduced in the ccc2 lines expressing $\mathrm{VviCCC}$ under salt stress, thus suggesting its role in shoot $\mathrm{Cl}^{-}$exclusion (Henderson et al., 2015). Overall, the current literature suggests that, among the above-mentioned $\mathrm{Cl}^{-}$ channels and transporters, SLAC1 and NPF2.5 are most likely to play an important role in shoot and root $\mathrm{Cl}^{-}$exclusion.

\section{Vacuolar $\mathrm{Cl}^{-}$Sequestration: Another Possible Component for Plant Salt Stress Tolerance?}

The vacuole is an organelle that occupies up to $90 \%$ of the volume of plant cells (Gao et al., 2015). Depending on the plant species, cell type, and measurement method, reports of electrical difference across the tonoplast vary from -31 to +50 mV (Ginsburg and Ginzburg, 1974; Mertz and Higinbotham, 1976; Rona et al., 1980; Kikuyama, 1986; Miller et al., 2001; Wang et al., 2015). This electrochemical gradient across the tonoplast could possibly facilitate movement of $\mathrm{Cl}^{-}$from the cytosol to the vacuole through channels or transporters, even if vacuolar $\mathrm{Cl}^{-}$is higher than that of the cytosol. Furthermore, the rise of $\mathrm{Ca}^{2+}$ has been seen to cause a transient change in both the plasma membrane and tonoplast potentials in Nitella (Kikuyama, 1986). Furthermore, tonoplast potential is shown to be +9 in barley root cells treated with $0.5 \mathrm{mM} \mathrm{CaSO}_{4}$, and $+35 \mathrm{mV}$ when treated with $1 \mathrm{mM} \mathrm{KCl}+0.5 \mathrm{mM} \mathrm{CaSO}_{4}($ Mertz and Higinbotham, 1976), thus demonstrating the variability of tonoplast potential according to media. Under saline conditions, the tonoplast potential could be changed to be more negative or positive. Tonoplast potential in barley leaf mesophyll cells grown in non-saline conditions has been reported to be $-4 \mathrm{mV}$, whereas it waxed negatively to $-7 \mathrm{mV}$ in barley plants subjected to salinity, (although this is still close to 0) (Cuin et al., 2003). It is thus shown that a more negative tonoplast potential exists in salt grown plants, which would allow for a more efficient active transport of $\mathrm{Cl}^{-}$from the cytosol into the vacuole. The changes of tonoplast membrane potential induced by salinity may vary significantly between plant species, and cell types. A direct measurement of tonoplast potential in salt grown plants, of a species that is more intolerant to $\mathrm{Cl}^{-}$than $\mathrm{Na}^{+}$, would help answer the question of the importance of vacuolar $\mathrm{Cl}^{-}$in overall salt tolerance. If tonoplast potential is around zero in plants under salt stress which means the driven force for operating active transport is limited, then the movement of $\mathrm{Cl}^{-}$will be predominantly dependent on the $\mathrm{Cl}^{-}$gradient between the cytosol and vacuole, which may not allow the vacuole to sequestrate a large amount of $\mathrm{Cl}^{-}$. In terms of $\mathrm{Cl}^{-}$ vacuolar sequestration, after salt stress onset a certain time points (the time point could be varied in plant species and cell 
types), vacuolar $\mathrm{Cl}^{-}$concentration is higher than cytosol and thus the ion channels with the nature of "downhill" activity will not be able to help in the vacuolar sequestration process. In this case, vacuolar sequestration of $\mathrm{Cl}^{-}$is not likely to happen over a considerable period of time and is thus hardly an important component for plant salt tolerance. This challenges the proposed hypothesis that plants can store $\mathrm{Cl}^{-}$in vacuoles to maintain cytosolic ion homeostasis, since in the above case, without the active transport of $\mathrm{Cl}^{-}$, it cannot be moved from the cytosol to vacuole against the proposed $\mathrm{Cl}^{-}$gradient (high $\mathrm{Cl}^{-}$stored in vacuole). Possibly, with the high cost of ATP, $\mathrm{Cl}^{-}$transporters might play a role in this process. With tens of negative or positive tonoplast potentials, the expense on ATP for active $\mathrm{Cl}^{-}$transport by $\mathrm{Cl}^{-}$transporters can be significantly reduced and thus can allow plants to have a longer time period of vacuolar $\mathrm{Cl}^{-}$sequestration under salt stress. We argue here that if some plant species have tens of negative or positive tonoplast potentials under saline conditions, vacuolar $\mathrm{Cl}^{-}$sequestration could be one of the components of overall salt tolerance. Further studies are required to answer the above questions.

The location of AtCLCa, AtCLCb, AtCLCc, AtCLCg, and AtALMT9 $\mathrm{Cl}^{-}$channels and transporters are known in the tonoplast, (De Angeli et al., 2013; Wei et al., 2015), and hints at the possible contribution of the vacuolar sequestration of $\mathrm{Cl}^{-}$to salt tolerance in plants. Overexpression of the tonoplast located AtCLCc results in higher $\mathrm{Cl}^{-}$accumulation and increased overall salt tolerance in the overexpression line in wild type Arabidopsis (Nguyen et al., 2016; Hu et al., 2017). Also, overexpression of $G m C L C 1$ in soybean hair roots results in more $\mathrm{Cl}^{-}$sequestration in roots and thus less $\mathrm{Cl}^{-}$being transported to the soybean shoot (Wei et al., 2016). AtALMT9, (a malate-activated $\mathrm{Cl}^{-}$channel located in the tonoplast), is involved in vacuolar $\mathrm{Cl}^{-}$sequestration and is required for stomatal opening (De Angeli et al., 2013). Furthermore, AtALMT9 is transcriptionally up-regulated under salt stress, and almt 9 knockout mutants have reduced shoot accumulation of $\mathrm{Cl}^{-}$(Baetz et al., 2016). Altogether, the above results suggest that vacuolar $\mathrm{Cl}^{-}$sequestration might be another component for overall plant salt tolerance. However, large scale experiments are still needed to validate this supposition.

\section{INCONSISTENT RESULTS OF CL- CONTENT IN PLANT SPECIES WITH CONTRASTING SALINITY TOLERANCE: THE IMPORTANCE OF INTRACELLULAR DISTRIBUTION OF CL- IN PLANT SALT TOLERANCE}

It has been argued that plant salt tolerance is related to the ability to regulate both $\mathrm{Na}^{+}$and $\mathrm{Cl}^{-}$transport to avoid toxicity (Tavakkoli et al., 2011). Under salinity stress, the most tolerant Brassica species showed less accumulation of $\mathrm{Cl}^{-}$in the leaf than the sensitive one (Chakraborty et al., 2016). Interestingly, a significantly lower shoot $\mathrm{Cl}^{-}$concentration was found in the salt sensitive bread wheat variety Krichuaff, than in the tolerant variety Berkut, under mild saline conditions (Genc et al., 2010). Also, $\mathrm{Cl}^{-}$concentration in the xylem sap extracted from cut stems is significantly lower in melon, (which is relatively salt sensitive), than in pumpkin grafted on melon (which is relatively salt tolerant) (Edelstein et al., 2011). With the knockout of the vacuolar $\mathrm{Cl}^{-}$channel ALMT9, which is highly expressed in the vasculature of shoots and roots, a reduced accumulation of $\mathrm{Cl}^{-}$in the shoot was observed, showing that vacuolar $\mathrm{Cl}^{-}$loading is crucial in controlling whole-plant ion movement during exposure to salinity (Baetz et al., 2016). The inconsistent relationship between $\mathrm{Cl}^{-}$accumulation and genotypic salt tolerance suggests that the intracellular distribution of $\mathrm{Cl}^{-}$is also important for plant salt tolerance. This is again in support of the viewpoint that vacuolar sequestration of $\mathrm{Cl}^{-}$is important in salt tolerance of plants.

\section{CONCLUSION}

Compared with well-studied $\mathrm{Na}^{+}$and $\mathrm{K}^{+}$, knowledge on $\mathrm{Cl}^{-}$in plant responses to salt stress is relatively limited. In this review, we argue that vacuolar $\mathrm{Cl}^{-}$sequestration could play a role in salt tolerance, at least in plant species that have either positive or negative tonoplast potential amounting to tens of $\mathrm{mV}$. We also suggest that the key channels/transporters of $\mathrm{Cl}^{-}$exclusion in plants under saline condition still need to be investigated. The restriction of shoot $\mathrm{Cl}^{-}$accumulation, both by root and/ or shoot $\mathrm{Cl}^{-}$exclusion, in different plant species is discussed in this review. Further, the toxicity of $\mathrm{Cl}^{-}$originating from $\mathrm{CaCl}_{2}$, (which is particularly relevant to horticultural crops and ornamental plants), is briefly reviewed, and compared with the toxicity of $\mathrm{Cl}^{-}$from $\mathrm{NaCl}$.

\section{AUTHOR CONTRIBUTIONS}

HW and ZL wrote the manuscript.

\section{FUNDING}

This work was supported by funding from Huazhong Agricultural University (11041910138) to HW and NSFC funding to ZL and to HW (31901464).

\section{ACKNOWLEDGMENTS}

We thank Prof. Sergey Shabala from the University of Tasmania, Australia for his help in preparation of this manuscript. We also thank Mr. Joseph Hartley from the University of Tasmania for his help in polishing the English of the manuscript. 


\section{REFERENCES}

Al-Whaibi, M. H., Siddiqui, M. H., and Basalah, M. O. (2012). Salicylic acid and calcium-induced protection of wheat against salinity. Protoplasma 249, 769778. doi: 10.1007/s00709-011-0322-1

Anschütz, U., Becker, D., and Shabala, S. (2014). Going beyond nutrition: Regulation of potassium homoeostasis as a common denominator of plant adaptive responses to environment. J. Plant Physiol. 171, 670-687. doi: 10.1016/j.jplph.2014.01.009

Apse, M. P., Aharon, G. S., Snedden, W. A., and Blumwald, E. (1999). Salt tolerance conferred by overexpression of a vacuolar $\mathrm{Na}^{+} / \mathrm{H}^{+}$antiport in Arabidopsis. Science 285 (80), 1256-1258. doi: 10.1126/science.285.5431.1256

Baetz, U., Eisenach, C., Tohge, T., Martinoia, E., and De Angeli, A. (2016). Vacuolar chloride fluxes impact ion content and distribution during early salinity stress. Plant Physiol. 172, 1167-1181. doi: 10.1104/pp.16.00183

Barbier-Brygoo, H., De Angeli, A., Filleur, S., Frachisse, J. M., Gambale, F., Thomine, S., et al. (2011). Anion channels/transporters in plants: from molecular bases to regulatory networks. Annu. Rev. Plant Biol. 62, 25-51. doi: 10.1146/annurev-arplant-042110-103741

Bazihizina, N., Colmer, T. D., Cuin, T. A., Mancuso, S., and Shabala, S. (2019). Friend or Foe? Chloride Patterning in Halophytes. Trends Plant Sci. 24, 142151. doi: $10.1016 / j . t p l a n t s .2018 .11 .003$

Borghesi, E., Carmassi, G., Uguccioni, M. C., Vernieri, P., and Malorgio, F. (2013). Effects of calcium and salinity stress on quality of lettuce in soilless culture. J. Plant Nutrit. 36, 677-690. doi: 10.1080/01904167.2012.721909

Borgognone, D., Cardarelli, M., Lucini, L., and Colla, G. (2014). Does CaCl2 play a role in improving biomass yield and quality of cardoon grown in a floating system under saline conditions? HortSci. 49, 1523-1528. doi: 10.21273/ HORTSCI.49.12.1523

Broadley, M., Brown, P., Cakmak, I., Rengel, Z., and Zhao, F. (2012) "Chapter 7-Function of nutrients: micronutrients." in Marschner's mineral nutrition of higher plants, 3rd ed. Marschner, P., Ed. (San Diego, CA, USA : Academic Press ) 191-248. doi: 10.1016/B978-0-12-384905-2.00007-8

Brumos, J., Talon, M., Bouhlal, R., and Colmenero-Flores, J. M. (2010). Clhomeostasis in includer and excluder citrus rootstocks: transport mechanisms and identification of candidate genes. Plant Cell Environ. 33, 2012-2027. doi: 10.1111/j.1365-3040.2010.02202.x

Carillo, P., Woodrow, P., Raimondi, G., El-Nakhel, C., Pannico, A., Kyriacou, M. C., et al. (2019). Omeprazole Promotes Chloride Exclusion and induces salt tolerance in greenhouse basil. Agron. 9, 355. doi: 10.3390/agronomy9070355

Cirillo1, C., De Micco, V., Arena, C., Carillo, P., Pannico, A., De Pascale, S., et al. (2019). Biochemical, physiological and anatomical mechanisms of adaptation of Callistemon citrinus and Viburnum lucidum to $\mathrm{NaCl}$ and $\mathrm{CaCl}_{2}$ salinization. Front. Plant Sci. 10, 742. doi: 10.3389/fpls.2019.00742

Chakraborty, K., Bose, J., Shabala, L., Eyles, A., and Shabala, S. (2016). Evaluating relative contribution of osmotolerance and tissue tolerance mechanisms toward salinity stress tolerance in three Brassica species. Physiol. Plant 158, 135-151. doi: 10.1111/ppl.12447

Chen, H., An, R., Tang, J. H., Cui, X. H., Hao, F. S., Chen, J., et al. (2007). Overexpression of a vacuolar $\mathrm{Na}^{+} / \mathrm{H}^{+}$antiporter gene improves salt tolerance in an upland rice. Mol. Breed. 19, 215-225. doi: 10.1007/s11032-006-9048-8

Chen, P., Yan, K., Shao, H., and Zhao, S. (2013). Physiological mechanisms for high salt tolerance in wild soybean (Glycine soja) from Yellow River Delta, China: Photosynthesis, osmotic regulation, ion flux and antioxidant capacity. PloS One 8, 1-12. doi: 10.1371/journal.pone.0083227

Collaa, G., Rouphaelb, Y., Jawadb, R., Kumara, P., Reac, E., and Cardarelli, M. (2013). The effectiveness of grafting to improve $\mathrm{NaCl}$ and $\mathrm{CaCl}_{2}$ tolerance in cucumber. Sci. Horiticul. 164, 380-391. doi: 10.1016/j.scienta.2013.09.023

Colmenero-Flores, J. M., Martínez, G., Gamba, G., Vázquez, N., Iglesias, D. J., Brumós, J., et al. (2007). Identification and functional characterization of cation-chloride cotransporters in plants. Plant J. 50, 278-292. doi: 10.1111/j.1365-313X.2007.03048.x

Cubero-Font, P., Maierhofer, T., Jaslan, J., Miguel A. Rosales, M. A., Espartero, J., et al. (2016). Silent S-type anion channel subunit SLAH1 gates SLAH3 open for chloride root-to-shoot translocation. Curr. Biol. 26, 1-8. doi: 10.1016/j. cub.2016.06.045

Cuin, T. A., Miller, A. J., Laurie, S. A., and Leigh, R. A. (2003). Potassium activities in cell compartments of salt-grown barley leaves. J. Exp. Bot. 54, 657-661. doi: $10.1093 / \mathrm{jxb} / \mathrm{erg} 072$
Cramer, G. R., Epstein, E., and Lauchli, A. (1991). Effects of sodium, potassium and calcium on salt-stressed barley. II. Elemental analysis. Physiol. Plant. 81, 197-202. doi: 10.1111/j.1399-3054.1991.tb02129.x

De Angeli, A., Zhang, J., Meyer, S., and Martinoia, E. (2013). AtALMT9 is a malate-activated vacuolar chloride channel required for stomatal opening in Arabidopsis. Nat. Commun. 4, 1804. doi: 10.1038/ncomms 2815

Deinlein, U., Stephan, A. B., Horie, T., Luo, W., Xu, G., and Schroeder, J. I. (2014). Plant salt-tolerance mechanisms. Trends Plant Sci. 19, 371-379. doi: 10.1016/j. tplants.2014.02.001

Dreyer, I., and Uozumi, N. (2011). Potassium channels in plant cells. FEBS J. 278, 4293-4303. doi: 10.1111/j.1742-4658.2011.08371.x

Edelstein, M., Plaut, Z., and Ben-Hur, M. (2011). Sodium and chloride exclusion and retention by non-grafted and grafted melon and Cucurbita plants. J. Exp. Bot. 62, 177-184. doi: 10.1093/jxb/erq255

Falke, L. C., Edwards, K. L., Pickard, B. G., and Misler, S. (1988). A stretchactivated anion channel in tobacco protoplasts. FEBS Lett. 237, 141-144. doi: 10.1016/0014-5793(88)80188-1

Fita, A., Rodríguez-Burruezo, A., Boscaiu, M., Prohens, J., and Vicente, O. (2015). Breeding and domesticating crops adapted to drought and salinity: A new paradigm for increasing food production. Front. Plant Sci. 6, 978. doi: 10.3389/ fpls.2015.00978

Flowers, T. J., and Hajibagheri, M. A. (2001). Salinity tolerance in Hordeum vulgare: ion concentrations in root cells of cultivars differing in salt tolerance Plant and Soil 231, 1-9. doi: 10.1023/A:1010372213938

Franco-Navarro, J. D., Brumós, J., Rosales, M. A., Cubero-Font, P., Talón, M., and Colmenero-Flores, J. M. (2016). Chloride regulates leaf cell size and water relations in tobacco plants. J. Exp. Bot. 67, 873-891. doi: 10.1093/jxb/erv502

Franco-Navarro, J. D., Rosales, M. A., Cubero-Font, P., Calvo, P., Álvarez, R., Diaz-Espejo, A., et al. (2019). Chloride as macronutrient increases water use efficiency by anatomically-driven reduced stomatal conductance and increased mesophyll diffusion to $\mathrm{CO} 2$ Running Title: $\mathrm{Cl}$ - simultaneously reduces g s and increases g m. Plant J. 99, 1-17. doi: 10.1111/tpj.14423

Gao, C., Zhao, Q., and Jiang, L. (2015). Vacuoles protect plants from high magnesium stress. Proc. Natl. Acad. Sci. 112, 2931-2932. doi: 10.1073/pnas.1501318112

Geilfus, C. M. (2018a). Chloride: From Nutrient to Toxicant. Plant Cell Physiol. 59, 877-886. doi: 10.1093/pcp/pcy071

Geilfus, C. M. (2018b). Review on the significance of chlorine for crop yield and quality. Plant Sci. 270, 114-122. doi: 10.1016/j.plantsci.2018.02.014

Genc, Y., Tester, M., and McDonald, G. K. (2010). Calcium requirement of wheat in saline and non-saline conditions. Plant Soil 327, 331-345. doi: 10.1007/ s11104-009-0057-3

Ginsburg, H., and Ginzburg, B. Z. (1974). Radial water and solute flows in roots of Zea mays: I. Water flow. J. Exp. Bot. 25, 28-35. doi: 10.1093/jxb/21.3.580

Gouiaa, S., Khoudi, H., Leidi, E. O., Pardo, J. M., and Masmoudi, K. (2012). Expression of wheat $\mathrm{Na}^{+} / \mathrm{H}^{+}$antiporter TNHXS1 and $\mathrm{H}^{+}$- pyrophosphatase TVP1 genes in tobacco from a bicistronic transcriptional unit improves salt tolerance. Plant Mol. Biol. 79, 137-155. doi: 10.1007/s11103-012-9901-6

Guan, R., Qu, Y., Guo, Y., Yu, L., Liu, Y., and Jiang, J. (2014). Salinity tolerance in soybean is modulated by natural variation in GmSALT3. Plant J. 80, 937-950. doi: $10.1111 /$ tpj.12695

Hamilton, E. S., Jensen, G. S., Maksaev, G., Katims, A., Sherp, A. M., and Haswell, E. S. (2015). Mechanosensitive channel MSL8 regulates osmotic forces during pollen hydration and germination. Science 350 (80), 438-441. doi: 10.1126/ science.aac6014

Hanin, M., Ebel, C., Ngom, M., Laplaze, L., and Masmoudi, K. (2016). New insights on plant salt tolerance mechanisms and their potential use for breeding. Front. Plant Sci. 7, 1-17. doi: 10.3389/fpls.2016.01787

Henderson, S. W., Baumann, U., Blackmore, D. H., Walker, A. R., Walker, R. R., and Gilliham, M. (2014). Shoot chloride exclusion and salt tolerance in grapevine is associated with differential ion transporter expression in roots. BMC Plant Biol. 14, 273. doi: $10.1186 / \mathrm{s} 12870-014-0273-8$

Henderson, S. W., Wege, S., Qiu, J., Blackmore, D. H., Walker, A. R., Tyerman, S. D., et al. (2015) Grapevine and Arabidopsis cation-chloride cotransporters localize to the Golgi and trans-Golgi network and indirectly influence longdistance ion transport and plant salt tolerance. Plant Physiol. 169, 2215-2229. doi: 10.1104/pp.15.00499

Herdean, A., Nziengui, H., Zsiros, O., Solymosi, K., Garab, G., Lundin, B., et al. (2016a). The Arabidopsis thylakoid chloride channel AtCLCe functions in 
chloride homeostasis and regulation of photosynthetic electron transport. Front. Plant Sci. 7, 1-15. doi: 10.3389/fpls.2016.00115

Herdean, A., Teardo, E., Nilsson, A. K., Pfeil, B. E., Johansson, O. N., Ünnep, R., et al. (2016b). A voltage-dependent chloride channel fine-tunes photosynthesis in plants. Nat. Commun. 7, 11654. doi: 10.1038/ncomms11654

Horie, T., Karahara, I., and Katsuhara, M. (2012). Salinity tolerance mechanisms in glycophytes: An overview with the central focus on rice plants. Rice 5, 1-18. doi: 10.1186/1939-8433-5-11

Hu, R., Zhu, Y., Wei, J., Chen, J., Shi, H., Shen, G., et al. (2017). Overexpression of PP2A-C5 that encodes the catalytic subunit 5 of protein phosphatase $2 \mathrm{~A}$ in Arabidopsis confers better root and shoot development under salt conditions. Plant Cell Environ. 40, 150-164. doi: 10.1111/pce.12837

Kikuyama, M. (1986). Tonoplast action potential of Characeae. Plant Cell Physiol. 27, 1461-1468. doi: 10.1093/oxfordjournals.pcp.a077246

Kurusu, T., Saito, K., Horikoshi, S., Hanamata, S., Negi, J., Yagi, C., et al. (2013). An S-type anion channel SLAC1 is involved in cryptogein-induced ion fluxes and modulates hypersensitive responses in tobacco BY-2 cells. PloS One 8, e70623. doi: 10.1371 /journal.pone. 0070623

Läuchli, A., James, R. A., Huang, C. X., McCully, M., and Munns, R. (2008). Cell-specific localization of $\mathrm{Na}^{+}$in roots of durum wheat and possible control points for salt exclusion. Plant Cell Environ. 31, 1565-1574. doi: 10.1111/j.1365-3040.2008.01864.x

Li, B., Qiu, J., Jayakannan, M., Xu, B., Li, Y., Mayo, G. M., et al. (2017a). AtNPF2.5 modulates chloride $\left(\mathrm{Cl}^{-}\right)$efflux from roots of Arabidopsis thaliana. Front. Plant Sci. 7, 2013. doi: 10.3389/fpls.2016.02013

Li, B., Tester, M., and Gilliham, M. (2017b). Chloride on the Move. Trends Plant Sci. 22, 236-248. doi: 10.1016/j.tplants.2016.12.004

Ligaba, A., Maron, L., Shaff, J., Kochian, L., and Piñeros, M. (2012). Maize ZmALMT2 is a root anion transporter that mediates constitutive root malate efflux. Plant Cell Environ. 35, 1185-1200. doi: 10.1111/j.1365-3040.2011.02479.x

Liu, X., Mak, M., Babla, M., Wang, F., Chen, G., Veljanoski, F., et al. (2014). Linking stomatal traits and expression of slow anion channel genes $\mathrm{HvSLAH1}$ and HvSLAC1 with grain yield for increasing salinity tolerance in barley. Front. Plant Sci. 5, 1-12. doi: 10.3389/fpls.2014.00634

Liu, Y., Yu, L., Qu, Y., Chen, J., Liu, X., Hong, H., et al. (2016). GmSALT3, which confers improved soybean salt tolerance in the field, increases leaf $\mathrm{Cl}$ - exclusion prior to $\mathrm{Na}+$ exclusion but does not improve early vigor under salinity. Front. Plant Sci. 7, 1485. doi: 10.3389/fpls.2016.01485

Maathuis, F. J. M. (2014). Sodium in plants: Perception, signalling, and regulation of sodium fluxes. J. Exp. Bot. 65, 849-858. doi: 10.1093/jxb/ert326

Maksaev, G., and Haswell, E. S. (2012). MscS-Like10 is a stretch-activated ion channel from Arabidopsis thaliana with a preference for anions. Proc. Natl. Acad. Sci. 109, 19015-19020. doi: 10.1073/pnas.1213931109

Marschner, H. (1995) Mineral nutrition in higher plants, 2nd Ed. London, UK: Academic Press.

Martinez, C. J., and Clark, M. W. (2012). Using reclaimed water for landscape irrigation. Gainesville, FL, USA: Florida Cooperative Extension Service, University of Florida.

Mertz, Jr., S. T., and Higinbotham, N. (1976). Transmembrane electropotential in barley roots as related to cell type, cell location, and cutting and aging effects. Plant Physiol. 57, 123-128. doi: 10.1104/pp.57.2.123

Meyer, S., Mumm, P., Imes, D., Endler, A., Weder, B., Al-Rasheid, K. A. S., et al. (2010). AtALMT12 represents an R-type anion channel required for stomatal movement in Arabidopsis guard cells. Plant J. 63, 1054-1062. doi: 10.1111/j.1365-313X.2010.04302.x

Miller, A. J., Cookson, S. J., Smith, S. J., and Wells, D. M. (2001). The use of microelectrodes to investigate compartmentation and the transport of metabolized inorganic ions in plants. J. Exp. Bot. 52, 541-549. doi: 10.1093/JEXBOT/52.356.541

Moya, J. L., Gómez-Cadenas, A., Primo-Millo, E., and Talon, M. (2003). Chloride absorption in salt-sensitive Carrizo citrange and salt-tolerant Cleopatra mandarin citrus rootstocks is linked to water use. J. Exp. Bot. 54, 825-833. doi: $10.1093 /$ jxb/erg064

Munns, R., and Tester, M. (2008). Mechanisms of salinity tolerance. Annu. Rev. Plant Biol. 59, 651-681. doi: 10.1146/annurev.arplant.59.032607.092911

Nackley, L. L., Barnes, C., and Oki, L. R. (2015) Investigating the impacts of recycled water on long-lived conifers. AoB Plants 7, plv035. doi: 10.1093/ aobpla/plv035
Negi, J., Matsuda, O., Nagasawa, T., Oba, Y., Takahashi, H., Kawai-Yamada, M., et al. (2008). $\mathrm{CO}_{2}$ regulator SLAC1 and its homologues are essential for anion homeostasis in plant cells. Nature 452, 483-486. doi: 10.1038/nature06720

Nguyen, C. T., Agorio, A., Jossier, M., Depré, S., Thomine, S., and Filleur, S. (2016). Characterization of the chloride channel-like, AtCLCg, involved in chloride tolerance in Arabidopsis thaliana. Plant Cell Physiol. 57, 764-775. doi: 10.1093/ $\mathrm{pcp} / \mathrm{pcv} 169$

Piñeros, M. A., Cançado, G. M. A., and Kochian, L. V. (2008). Novel properties of the wheat aluminum tolerance organic acid transporter (TaALMT1) revealed by electrophysiological characterization in Xenopus Oocytes: functional and structural implications. Plant Physiol. 147, 2131-2146. doi: 10.1104/pp.108.119636

Qiu, J., Henderson, S. W., Tester, M., Roy, S. J., and Gilliham, M. (2016). SLAH1, a homologue of the slow type anion channel SLAC1, modulates shoot $\mathrm{Cl}^{-}$ accumulation and salt tolerance in Arabidopsis thaliana. J. Exp. Bot. 67, 44954505. doi: $10.1093 / \mathrm{jxb} / \mathrm{erw} 237$

Rahman, A., Nahar, K., Hasanuzzaman, M., and Fujita M. (2016). Calcium supplementation improves $\mathrm{Na}+/ \mathrm{K}+$ ratio, antioxidant defense and glyoxalase systems in salt-stressed rice seedlings. Front. Plant Sci. 7, 609. doi: 10.3389/ fpls.2016.00609

Raven, J. A. (2017). Chloride: Essential micronutrient and multifunctional beneficial ion. J. Exp. Bot. 68, 359-367. doi: 10.1093/jxb/erw421

Rona, J. P., Pitman, M. G., Lüttge, U., and Ball, E. (1980). Electrochemical data on compartmentation into cell wall, cytoplasm, and vacuole of leaf cells in the CAM genus Kalanchoë. J. Membr. Biol. 57, 25-35. doi: 10.1007/BF01868983

Seemann, J. R., and Critchley, C. (1985). Effects of salt stress on the growth, ion content, stomatal behaviour and photosynthetic capacity of a salt-sensitive species, Phaseolus vulgaris L. Planta. 164, 151-162. doi: 10.1007/BF00396077

Shabala, S., Babourina, O., and Newman, I. (2000). Ion-specific mechanisms of osmoregulation in bean mesophyll cells. J. Exp. Bot. 51, 1243-1253. doi: 10.1093/jexbot/51.348.1243

Shabala, S., Demidchik, V., Shabala, L., Cuin, T. A., Smith, S. J., Miller, A. J., et al. (2006). Extracellular $\mathrm{Ca} 2+$ ameliorates $\mathrm{NaCl}$-induced $\mathrm{K}+$ loss from Arabidopsis root and leaf cells by controlling plasma membrane $\mathrm{K}+$-permeable channels. Plant Physiol. 141, 1653-1665. doi: 10.1104/pp.106.082388

Shabala, S., and Pottosin, I. (2014). Regulation of potassium transport in plants under hostile conditions: Implications for abiotic and biotic stress tolerance. Physiol. Plant 151, 257-279. doi: 10.1111/ppl.12165

Shabala, S., Shabala, L., Van Volkenburgh, E., and Newman, I. (2005). Effect of divalent cations on ion fluxes and leaf photochemistry in salinized barley leaves. J. Exp. Bot. 56, 1369-1378. doi: 10.1093/jxb/eri138

Skerrett, M., and Tyerman, S. D. (1994). A channel that allows inwardly directed fluxes of anions in protoplasts derived from wheat roots. Planta 192, 295-305. doi: $10.1007 / \mathrm{BF} 00198563$

Tavakkoli, E., Fatehi, F., Coventry, S., Rengasamy, P., and McDonald, G. K. (2011). Additive effects of $\mathrm{Na}^{+}$and $\mathrm{Cl}$ - ions on barley growth under salinity stress. J. Exp. Bot. 62, 2189-2203. doi: 10.1093/jxb/erq422

Tavakkoli, E., Rengasamy, P., and McDonald, G. K. (2010). High concentrations of $\mathrm{Na}^{+}$and $\mathrm{Cl}$ ions in soil solution have simultaneous detrimental effects on growth of faba bean under salinity stress. J. Exp. Bot. 61, 4449-4459. doi: 10.1093/jxb/ erq251

Teakle, N. L., Flowers, T. J., Real, D., and Colmer, T. D. (2007). Lotus tenuis tolerates the interactive effects of salinity and waterlogging by "excluding" $\mathrm{Na}^{+}$ and $\mathrm{Cl}^{-}$from the xylem. J. Exp. Bot. 58, 2169-2180. doi: 10.1093/jxb/erm102

Teakle, N. L., and Tyerman, S. D. (2010). Mechanisms of $\mathrm{Cl}^{-}$transport contributing to salt tolerance. Plant Cell Environ. 33, 566-589. doi: 10.1111/j.1365-3040.2009.02060.x

van Ittersum, M. K., van Bussel, L. G. J., Wolf, J., Grassini, P., van Wart, J., Guilpart, N., et al. (2016). Can sub-Saharan Africa feed itself? Proc. Natl. Acad. Sci. 113, 14964-14969. doi: 10.1073/pnas.1610359113

Wang, M., Zheng, Q., Shen, Q., and Guo, S. (2013). The critical role of potassium in plant stress response. Int. J. Mol. Sci. 14, 7370-7390. doi: 10.3390/ijms 14047370

Wang, Y., Dindas, J., Rienmüller, F., Krebs, M., Waadt, R., Schumacher, K., et al. (2015). Cytosolic $\mathrm{Ca}^{2+}$ signals enhance the vacuolar ion conductivity of bulging Arabidopsis root hair cells. Mol. Plant 8, 1665-1674. doi: 10.1016/j. molp.2015.07.009

Wang, Z., Li, J., and Li, Y. (2017). Using reclaimed water for agricultural and landscape irrigation in China: a review. Irrig. Drain. 66, 672-686. doi: 10.1002/ $\operatorname{ird} .2129$ 
Wege, S., Gilliham, M., and Henderson, S. W. (2017). Chloride: Not simply a "cheap osmoticum", but a beneficial plant macronutrient. J. Exp. Bot. 68, 30573069. doi: 10.1093/jxb/erx050

Wei, P., Wang, L., Liu, A., Yu, B., and Lam, H.-M. (2016). GmCLC1 confers enhanced salt tolerance through regulating chloride accumulation in soybean. Front. Plant Sci. 7, 1-11. doi: 10.3389/fpls.2016.01082

Wei, Q. J., Gu, Q. Q., Wang, N. N., Yang, C. Q., and Peng, S. A. (2015). Molecular cloning and characterization of the chloride channel gene family in trifoliate orange. Biol. Plant 59, 645-653. doi: 10.1007/s10535-015-0532-Z

White, P., and Broadley, M. R. (2001). Chloride in soils and its uptake and movement within the plant: A review. Ann. Bot. 88, 967-988. doi: 10.1006/anbo.2001.1540

$\mathrm{Wu}, \mathrm{H}$. (2018). Plant salt tolerance and $\mathrm{Na}+$ sensing and transport. Crop J. 6, 215225. doi: 10.1016/j.cj.2018.01.003

Wu, H., Shabala, L., Azzarello, E., Huang, Y., Pandolfi, C., Su, N., et al. (2018a). Na + extrusion from the cytosol and tissue-specific $\mathrm{Na}+$ sequestration in roots confer differential salt stress tolerance between durum and bread wheat. J. Exp. Bot. 69, 3987-4001. doi: 10.1093/jxb/ery194

Wu, H., Shabala, L., Liu, X., Azzarello, E., Zhou, M., Pandolfi, C., et al. (2015). Linking salinity stress tolerance with tissue-specific $\mathrm{Na}^{+}$sequestration in wheat roots. Front. Plant Sci. 6, 71. doi: 10.3389/fpls.2015.00071

Wu, H., Shabala, L., Shabala, S., and Giraldo, J. P. (2018b). Hydroxyl radical scavenging by cerium oxide nanoparticles improves Arabidopsis salinity tolerance by enhancing leaf mesophyll potassium retention. Environ. Sci. Nano 5, 1567-1583. doi: 10.1039/c8en00323h

Wu, H., Zhang, X., Giraldo, J. P., and Shabala, S. (2018c). It is not all about sodium: revealing tissue specificity and signalling roles of potassium in plant responses to salt stress. Plant Soil 431, 1-17. doi: 10.1007/s11104-018-3770-y

Xu, X., Magen, H., Tarchitzky, J., and Kafkafi, U. (1999). Advances in chloride nutrition of plants. Adv. Agron. 68,97-150. doi: 10.1016/S0065-2113(08)60844-5
Xu, D., Wang, W., Gao, T., Fang, X., Gao, X., Li, J., et al. (2017). Calcium alleviates decreases in photosynthesis under salt stress by enhancing antioxidant metabolism and adjusting solute accumulation in Calligonum mongolicum. Conserv. Physiol. 5, cox060. doi: 10.1093/conphys/cox060

Yang, Q., Chen, Z. Z., Zhou, X. F., Yin, H. B., Li, X., Xin, X. F., et al. (2009) Overexpression of SOS (salt overly sensitive) genes increases salt tolerance in transgenic Arabidopsis. Mol. Plant 2, 22-31. doi: 10.1093/mp/ssn058

Yue, Y., Zhang, M., Zhang, J., Duan, L., and Li, Z. (2012). SOS1 gene overexpression increased salt tolerance in transgenic tobacco by maintaining a higher $\mathrm{K}^{+} / \mathrm{Na}^{+}$ ratio. J. Plant Physiol. 169, 255-261. doi: 10.1016/j.jplph.2011.10.007

Zhang, H. X., and Blumwald, E. (2001). Transgenic salt-tolerant tomato plants accumulate salt in foliage but not in fruit. Nat. Biotechnol. 19, 765-768. doi: $10.1038 / 90824$

Zhang, H., Zhao, F.-G., Tang, R.-J., Yu, Y., Song, J., Wang, Y., et al. (2017). Two tonoplast MATE proteins function as turgor-regulating chloride channels in Arabidopsis. Proc. Natl. Acad. Sci. 114, E2036-E2045. doi: 10.1073/ pnas. 1616203114

Conflict of Interest: The authors declare that the research was conducted in the absence of any commercial or financial relationships that could be construed as a potential conflict of interest.

Copyright (c) $2019 \mathrm{Wu}$ and $\mathrm{Li}$. This is an open-access article distributed under the terms of the Creative Commons Attribution License (CC BY). The use, distribution or reproduction in other forums is permitted, provided the original author(s) and the copyright owner(s) are credited and that the original publication in this journal is cited, in accordance with accepted academic practice. No use, distribution or reproduction is permitted which does not comply with these terms. 